\title{
PENGEMBANGAN MEDIA CD INTERAKTIF MATA PELAJARAN TEKNOLOGI INFORMASI DAN KOMUNIKASI KELAS VII SMP NEGERI 6 SINGARAJA
}

\author{
Oleh: \\ Ketut Erni Suardani \\ Jurusan Pendidikan Teknik Informatika
}

\begin{abstract}
ABSTRAK
Penelitian ini bertujuan : (1) Untuk merancang dan mengimplementasikan Pengembangan Media CD Interaktif Mata Pelajaran Teknologi Informasi dan Komunikasi Kelas VII SMP Negeri 6 Singaraja. (2) Untuk mengetahui respon siswa terhadap Pengembangan Media CD Interaktif Mata Pelajaran Teknologi Informasi dan Komunikasi Kelas VII SMP Negeri 6 Singaraja

Subyek penelitian adalah seluruh siswa kelas VII B4 di SMP Negeri 6 Singaraja tahun pelajaran 2009/2010 sebanyak 42 orang. Penelitian yang dilakukan adalah penelitian pengembangan. Data yang dikumpulkan yaitu data respon siswa terhadap pengembangan Media CD Interaktif Mata Pelajaran Teknologi Informasi dan Komunikasi dengan mengunakan angket. Data respon siswa dan data uji ahli dianalisis secara deskriptif. Data hasil uji ahli digunakan sebagai masukan untuk memperbaiki kualitas Media CD Interaktif.

Hasil penelitian ini berupa CD Interaktif TIK dan hasil respon siswa terhadap pengembangan media CD interaktif TIK tersebar pada kategori positif $45 \%$. Rata-rata skor respon siswa yaitu 64,95 sehingga respon siswa dikategorikan positif.
\end{abstract}

Kata-kata kunci: CD Interaktif, TIK, Penelitian Pengembangan, Respon Siswa.

\begin{abstract}
The study aimed to: (1) design and implement the development of interactive CD Media of Technology Information and Comunication (ICT) subject for VII grade student of SMPN 6 Singaraja. (2) To know the students respond toward imply the development of interactive CD Media of Technology Information and Comunication (ICT) subject for VII grade student of SMPN 6 Singaraja.

The subject of the study was all student of VII B4 class of SMPN 6 Singaraja in the academic year to 2009 / 2010, which consisted of 42 students. The study was research development. The data were collected in the form of students respond toward the development of interactive CD Media. The instrument used in this study was questionnaire. The data of students respond and the data judges were analysed descriptively. The judge's data were used for suggestion to improve the quality of interactive CD Media.

The results of the study were interactive CD of ICT and the students respond toward the development of interactive CD TIK. The result ranged at positive category $45 \%$. The mean score of students respond was 64,95 and it was categorized positive.
\end{abstract}

Key Words: Interactive CD ICT, Reasearch and Development, Response

Pengembangan Media Cd Interaktif. .(Ketut Erni Suardani) 


\section{PENDAHULUAN}

SMP Negeri 6 Singaraja merupakan salah satu sekolah menengah yang telah menerapkan kurikulum KTSP dalam kegiatan pembelajaran. Semua mata pelajaran telah menggunakan kurikulum KTSP baik dari metode pembelajarannya sampai pada pengaplikasiannya, dimana salah satunya mata pelajaran TIK Kelas VII.

Dari hasil observasi dan wawancara dengan guru mata pelajaran TIK kelas VII yang dilakukan di SMP Negeri 6 Singaraja, pembelajaran TIK kelas VII masih kurang menarik minat siswa karena banyak tenaga pendidik dalam menyampaikan materi ajar tanpa menggunakan media melainkan hanya dengan media kapur dan papan sehingga sering kali timbul kebosanan dalam diri siswa untuk belajar, guru dalam mengajar lebih banyak berceramah sehingga siswa sering kali tidak menghiraukan apa yang diajarkan guru. Karakteristik siswa dapat dilihat berdasarkan daya tangkap siswa yang sangat berbeda antar siswa satu dengan siswa lain, siswa kurang mampu menggambarkan materi - materi yang telah disampaikan sehingga siswa tidak tertarik untuk belajar dan memahami lebih dalam materi TIK yang diajarkan. Kurangnya respon siswa terhadap materi ajar, pada akhirnya mengakibatkan pembelajaran tidak berjalan dengan kondusif.

Berdasarkan nilai raport mata pelajaran TIK Kelas VII SMPN 6 Singaraja, merupakan akibat kurangnya penggunaan media pembelajaran dalam belajar mengajar, dimana penggunaan media pembelajaran dapat menghemat waktu persiapan mengajar, meningkatkan motivasi dan respon belajar siswa serta hasil belajar siswa. Tanpa bantuan media pembelajaran, persepsi siswa terhadap materi TIK menjadi sangat abstrak maka dari itu isi dari sebuah media harus sesuai dengan kompetensi dasar dan indikator pencapaian yang ingin dicapai. Hal tersebut akan semakin buruk jika kita tidak sadar bahwa strategi pembelajaran yang berpusat pada siswa (student centered learning) juga memerlukan media dengan harapan agar mampu merangsang siswa untuk belajar mandiri. Media yang dibuat tersebut bukan hanya sebuah media yang menampilkan materi ajar saja. Media pembelajaran tersebut harus interaktif, karena media pembelajaran interaktif dapat menyajikan materi pembelajaran secara lebih menyeluruh baik dari segi abstraksi, ukuran dimensi, keruntutan maupun soal latihan. Media pembelajaran yang akan dikembangkan penulis dalam penelitian ini akan dikemas dalam bentuk CD (Compact Disk).

JPTK, UNDIKSHA, Vol. 11 , No. 1, Januari 2014 : 13 - 24 
Berdasarkan latar belakang diatas, peneliti ingin mengembangkan media pembelajaran dalam penelitian ini dengan judul" Pengembangan Media CD Interaktif Mata Pelajaran Teknologi Informasi Dan Komunikasi Kelas VII SMP Negeri 6 Singaraja ”. Ada beberapa rumusan masalah yang dikaji dalam penelitian ini yaitu : (1) Bagaimana merancangan dan pengimplementasian Pengembangan Media CD Interaktif Mata Pelajaran Teknologi Informasi dan Komunikasi Kelas VII SMP Negeri 6 Singaraja (2) Bagaimana respon siswa terhadap Pengembangan Media CD Interaktif Mata Pelajaran Teknologi Informasi dan Komunikasi Kelas VII SMP Negeri 6 Singaraja. Tujuan dari penelitian ini adalah (1) Untuk merancang dan mengimplementasikan Pengembangan Media CD Interaktif Mata Pelajaran Teknologi Informasi dan Komunikasi Kelas VII SMP Negeri 6 Singaraja (2) Untuk mengetahui respon siswa terhadap Pengembangan Media CD Interaktif Mata Pelajaran Teknologi Informasi dan Komunikasi Kelas VII SMP Negeri 6 Singaraja. Manfaat penelitian ini ditujukan kepada siswa, guru, sekolah, dan bagi peneliti lain.

\section{METODE PENELITIAN}

Jenis penelitian yang digunakan untuk mengembangkan penelitian ini adalah Research and Development yang bertujuan untuk menghasilkan sebuah produk berupa CD Interaktif Teknologi Informasi dan Komunikasi (TIK) Kelas VII di SMP Negeri 6 Singaraja dan menguji keefektifan produk tersebut. Dalam penelitian ini menggunakan dua model yaitu Dick and Carey untuk pengembangan isi media CD Interaktif dan Sequensial Linier untuk pengembangan media CD Interaktif.

Dengan subyek penelitian adalah siswa kelas VII B ${ }_{4}$ di SMP Negeri 6 Singaraja dan ahli isi serta ahli media pembelajaran. Jumlah siswa keseluruhan yaitu 42 orang, siswa laki - laki berjumlah 22 orang dan jumlah siswa perempuan 20 orang. Tahapan-tahapan yang dilakukan dalam pengembangan media CD Interaktif adalah sebagai berikut : 


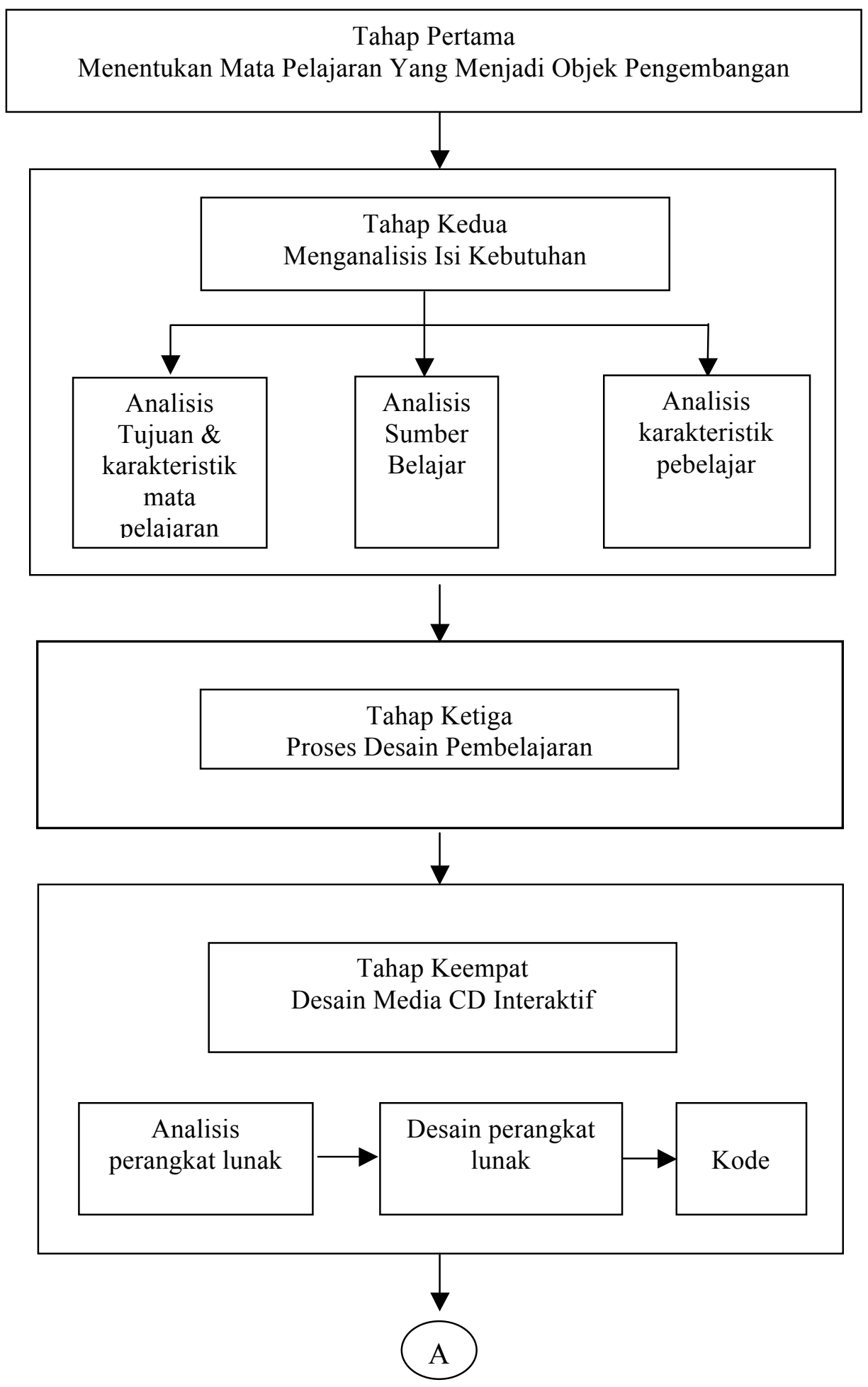

JPTK, UNDIKSHA, Vol. 11 , No. 1, Januari 2014 : 13 - 24 


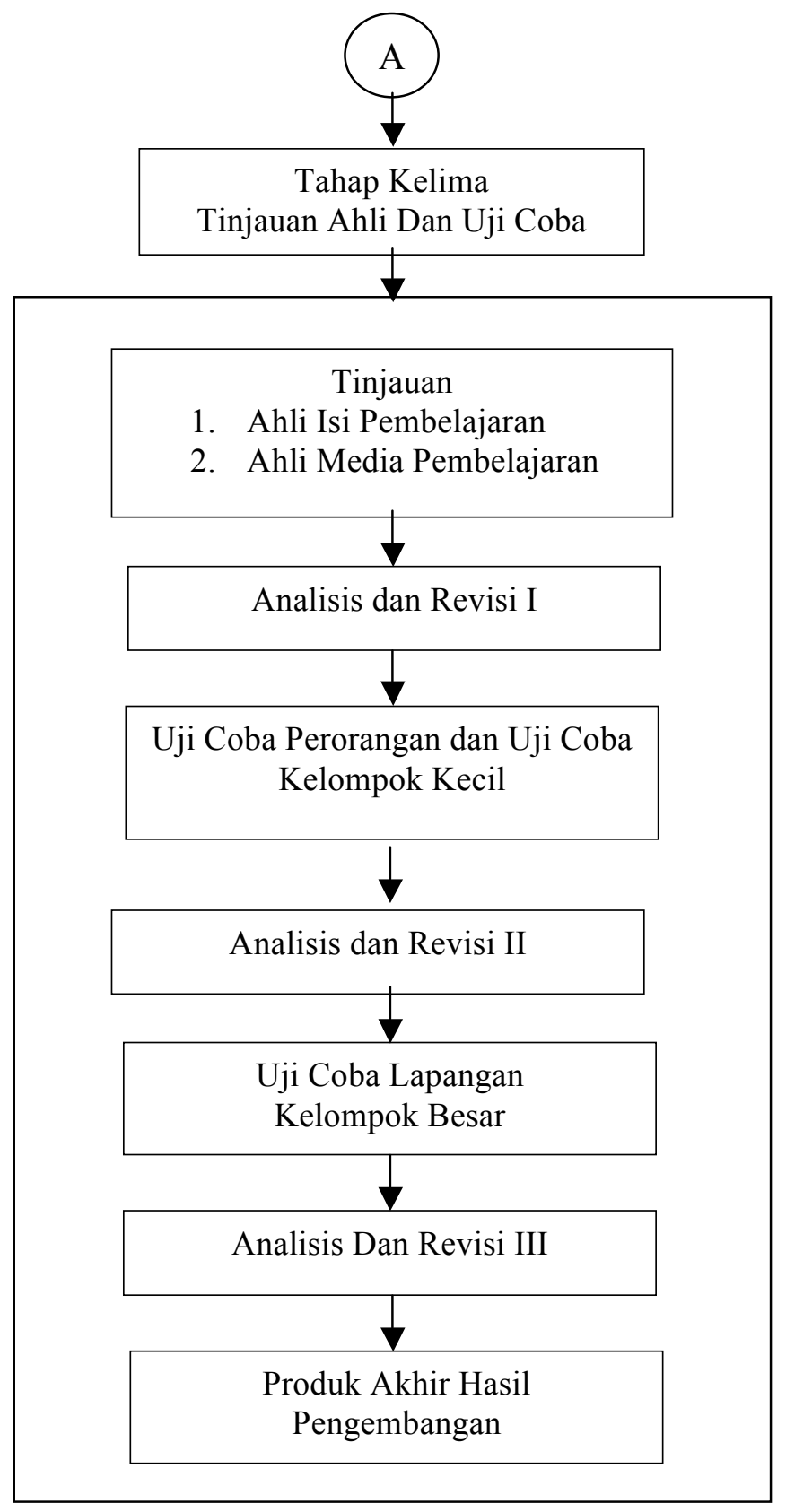

Gambar 1. Desain Pengembangan Media CD Interaktif (Santyasa : 2009)

Pengembangan ini dilakukan dengan 5 tahapan mulai dari menentukan mata pelajaran yang menjadi objek pengembangan, menganalisis isi kebutuhan, proses desain pembelajaran, desain media cd interaktif menggunakan sequensial linier, tinjauan ahli dan uji coba produk. Adapun Instrumen Penelitian dan Teknik Pengumpulan Data yang digunakan dalam penelitian ini dapat disajikan pada tabel 1 berikut: 
Tabel 1. Instrumen Penelitian dan Teknik Pengumpulan Data

\begin{tabular}{|l|l|l|l|l|}
\hline No & \multicolumn{1}{|c|}{ Jenis Data } & Metode & $\begin{array}{c}\text { Alat Pengumpulan } \\
\text { Data }\end{array}$ & \multicolumn{1}{|c|}{ Sumber Data } \\
\hline 1 & $\begin{array}{l}\text { Informasi tentang } \\
\text { sumber belajar }\end{array}$ & Wawancara & $\begin{array}{l}\text { Pertanyaan } \\
\text { wawancara }\end{array}$ & $\begin{array}{l}\text { Guru Mata } \\
\text { Pelajaran TIK }\end{array}$ \\
\hline 2 & Karakteristik siswa & Angket & Angket & Siswa \\
\hline 3 & $\begin{array}{l}\text { Validitas CD } \\
\text { Interaktif }\end{array}$ & Angket & Angket & Ahli \\
\hline 4 & Respon Siswa & Angket & Angket & Siswa \\
\hline
\end{tabular}

Analisis ini didasarkan pada atau dilakukan dengan menggunakan ukuran - ukuran statistik, dalam hal ini rata-rata kelas $(\bar{X})$ dari respon siswa, Mean $(\mathrm{M})$, dan Standar Deviasi (SD). Untuk memperoleh skor respon siswa dihitung dengan rumus :

$$
\bar{X}=\frac{\sum X}{N} \quad S D=\sqrt{\frac{\sum x^{2}}{N}}
$$

Keterangan :

$\bar{X} \quad$ : Rata - rata hitung respon siswa dalam satu kelas

$\sum X:$ Total Skor respon siswa dalam satu kelas

$\mathrm{N} \quad$ : Jumlah siswa dalam satu kelas

Patokan yang digunakan untuk mengkonversikan respon siswa terhadap Pengembangan CD Interaktif ditunjukan pada tabel 2 berikut :

Tabel 2. Tabel Konversi Respon Siswa

(Sudijono : 1995)

\begin{tabular}{|c|l|}
\hline \multicolumn{1}{|c|}{ Rentangan } & \multicolumn{1}{c|}{ Respon Siswa } \\
\hline $\bar{X} \geq \mathrm{M}+1,5 \mathrm{SD}$ & Sangat Positif \\
\hline $\mathrm{M}+0,5 \mathrm{SD} \leq \bar{X} \leq \mathrm{M}+1,5 \mathrm{SD}$ & Positif \\
\hline $\mathrm{M}-0,5 \mathrm{SD} \leq \bar{X} \leq \mathrm{M}+0,5 \mathrm{SD}$ & Cukup Positif \\
\hline $\mathrm{M}-1,5 \mathrm{SD} \leq \bar{X} \leq \mathrm{M}-0,5 \mathrm{SD}$ & Kurang Positif \\
\hline $\bar{X} \leq \mathrm{M}-1,5 \mathrm{SD}$ & Sangat Kurang Positif \\
\hline
\end{tabular}

JPTK, UNDIKSHA, Vol. 11 , No. 1, Januari $2014: 13$ - 24 


\section{HASIL PENELITIAN}

1. Hasil Implementasi Program Media Cd Interaktif

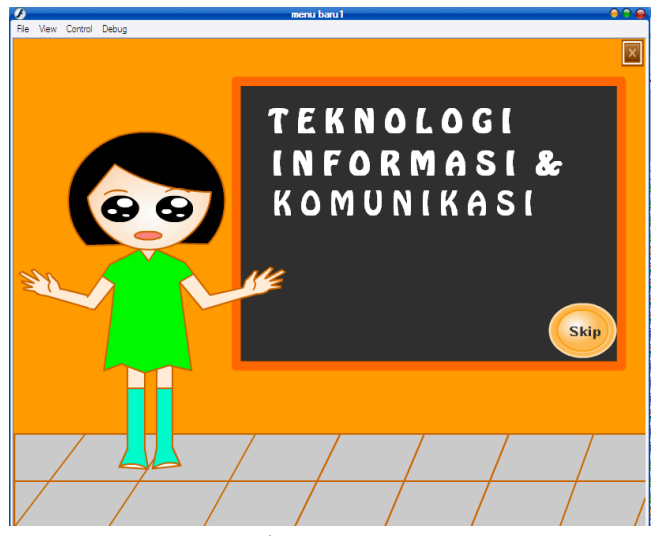

Gambar 1

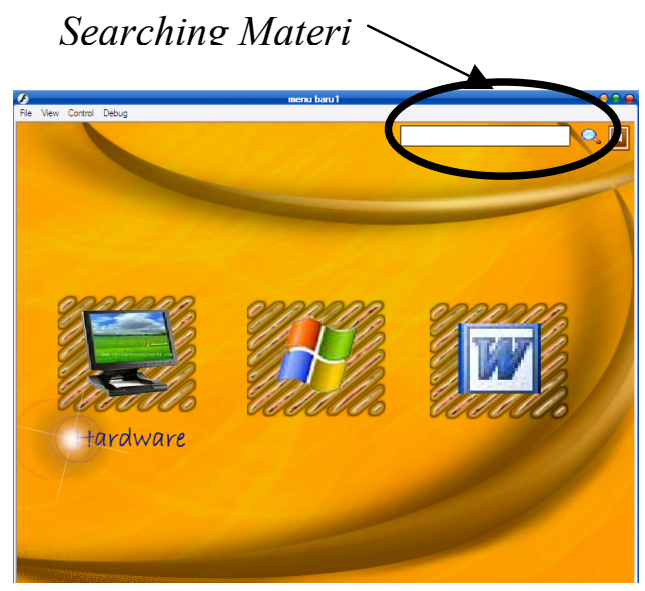

Gambar 3

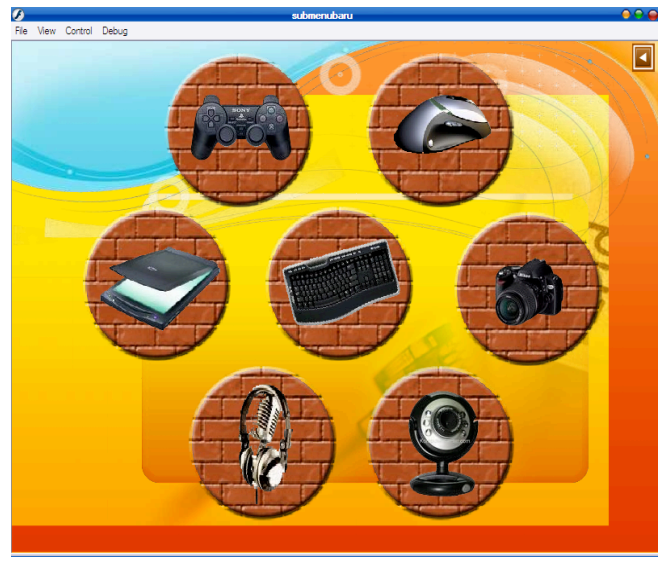

Gambar 5

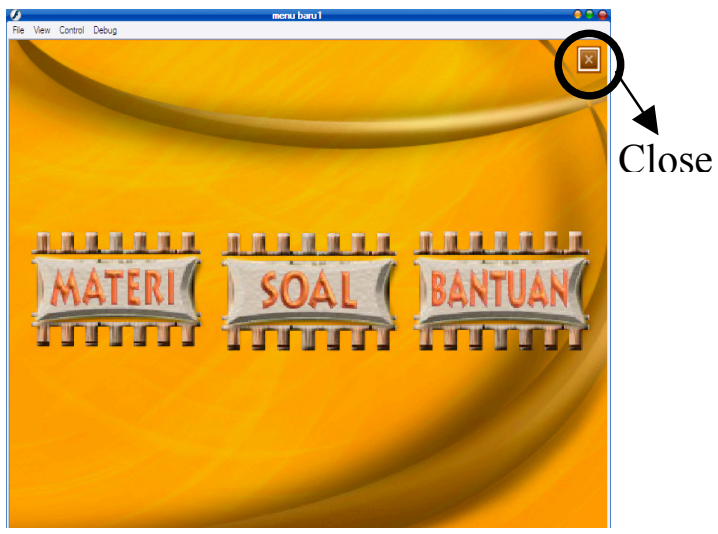

Gambar 2

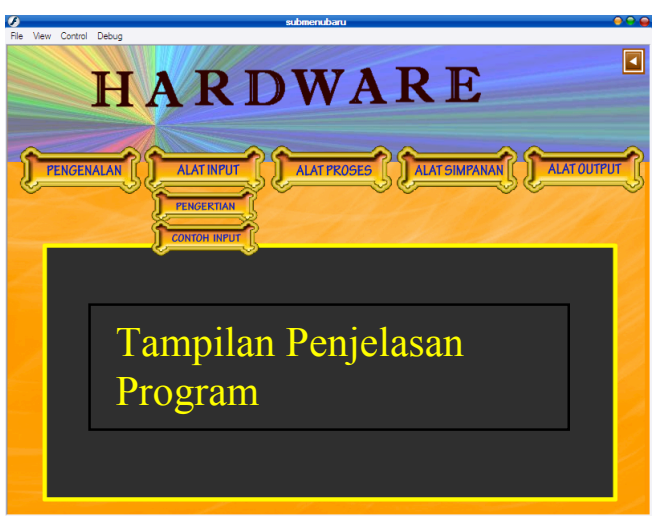

Gambar 4

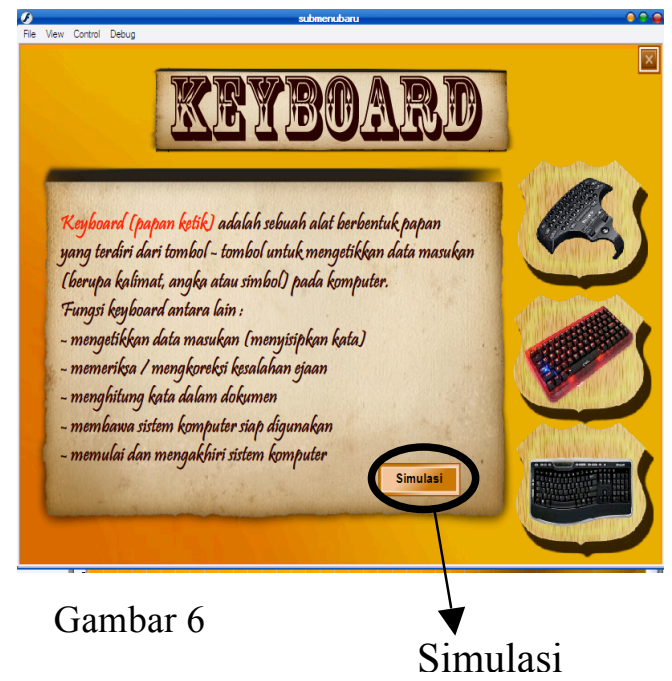


Dari hasil uji coba yang dilakukan penulis terhadap kebutuhan pemakai, yaitu (1) Media CD Interaktif ini menarik perhatian siswa, oleh sebab itu peneliti memilih memilih warna orange sebagai warna dasar karena warna orange memiliki makna kehangatan, semangat, antusiasme. Dari segi tampilannya media ini menngunakan kartun yang bertujuan untuk mengajak pengguna untuk belajar TIK. (2) Perangkat lunak harus mudah digunakan, media ini sangat mudah digunakan karena dalam media ini telah terdapat menu bantuan yang menjadi petunjuk dalam penggunaan media CD Interaktif ini. Media ini juga ditampilkan dengan sederhana, dimana setiap buttonnya menampilkan suara dan tulisan dari button tersebut yang dapat membantu pengguna lebih mudah memahami materi yang ada. (3) Perangkat lunak memiliki tampilan yang interaktif, pada media ini tampilan interaktifnya dapat kita lihat pada materi terdapat searching untuk mencari materi. Searching ini sangat membantu siswa melatih ingatannya serta ketrampilannya. Selain itu media ini juga terdapat soal latihan yang dapat langsung digunakan oleh pengguna. Soal yang terdapat pada media ini dapat langsung memeberikan balikan berupa hasil yang mereka peroleh dalam mengerjakan soal tersebut.

Hasil identifikasi dan implementasi dari proses kerja adalah : (a) Pada saat program dijalankan maka akan ditampilkan menu utama yang ditampilkan dalam animasi kartun siswi yang menyampaikan kompetensi dasar, pada sisi kanan atas tombol close untuk mengakhiri program. Pada sisi kanan bawah terdapat tombol skip yang berguna untuk melewati intro menuju halaman utama. (b) Halaman utama akan ditampilkan setelah intro selesai atau setelah tombol skip ditekan. Pada halaman ini terdapat tombol Close, tombol Materi, tombol Soal, tombol Bantuan. (c) Pada saat pemakai memilih Close maka halaman utama akan tertutup, dengan kata lain tombol Close digunakan untuk menutup atau mengakhiri program. (d) Jika tombol Materi diklik maka akan muncul 3 materi yang dipelajari pada kelas VII semester II, adapun materi yang terdapat pada menu materi adalah Hardware, Software dan Aplikasi. Pada pojok kanan atas selain terdapat tombol close juga terdapat menu search untuk mempermudah pengguna mencari materi. (e) Jika tombol Menu Hardware diklik maka akan munculkan menu hardware yang menampilkan menu pilihan pengenalan perangkat keras komputer, alat input, alat proses, alat simpanan dan alat output. Pada masing masing menu pilihan tersebut akan memberikan pilihan yang lebih spesifik lagi dan menampilkan video seperti pengenalan alat input dan contohnya, pengenalan alat proses dan contohnya, pengenalan alat simpanan dan contohnya serta pengenalan alat output beserta contohnya. (f) Jika tombol

JPTK, UNDIKSHA, Vol. 11 , No. 1, Januari 2014 : 13 - 24 
Menu Software diklik maka akan muncul menu software yang menampilkan menu pilihan pengenalan perangkat lunak komputer, bahasa pemrograman, sistem operasi, sistem utility dan aplikasi. Menu ini sama dengan menu hardware yang menampilkan menu pilihan yang berisi pengenalan tentang software beserta contohnya dan menu ini juga menampilkan video. (g) Jika tombol Menu Aplikasi diklik maka akan muncul menu aplikasi yang menampilkan menu pilihan pengenalan perangkat lunak aplikasi, toolbar pada microsoft word, cara akses dan operasi dasar. Pada menu ini menampilkan video dari masing - masing menu pilihan tersebut.

\section{Respon Siswa}

Sebaran skor respon siswa terhadap pengembangan media CD Interaktif dapat disajikan pada tabel 3 .

Tabel 3. Hasil Konversi Respon Siswa

\begin{tabular}{|c|l|r|r|l|}
\hline No & Kelas Interval & Frekuensi & Persentase & \multicolumn{1}{|c|}{ Kategori } \\
\hline 1 & $71,65 \leq \bar{X}$ & 0 & $0 \%$ & Sangat Positif \\
\hline 2 & $67,19 \leq \bar{X} \leq 71,65$ & 19 & $45 \%$ & Positif \\
\hline 3 & $62,72 \leq \bar{X} \leq 67,19$ & 13 & $31 \%$ & Cukup Positif \\
\hline 4 & $58,25 \leq \bar{X} \leq 62,72$ & 6 & $14 \%$ & Kurang Positif \\
\hline 5 & $\bar{X} \leq 58,25$ & 4 & $10 \%$ & Sangat Kurang Positif \\
\hline
\end{tabular}

Hasil analisis data menunjukkan skor rata - rata respon siswa sebesar 64,95 dengan kategori positif.

\section{PEMBAHASAN}

Berdasarkan atas analisis sumber belajar yang dilakukan penulis, bahwa media CD Interaktif sangat diperlukan baik itu oleh guru sebagai pengajar dan siswa sebagai pebelajar, khususnya pada mata pelajaran TIK kelas VII di SMP Negeri 6 Singaraja. Penyampaian materi yang dilakukan secara teoritis, mengakibatkan pemahaman siswa terhadap mata pelajaran TIK kurang. Kurangnya pemahaman siswa disebabkan karena siswa sangat membutuhkan sebuah gambaran yang jelas terhadap suatu materi sehingga siswa menjadi lebih memahami hardware, software dan aplikasi komputer. Hasil analisis tersebut telah memberikan inspirasi kepada penulis untuk mengembangkan CD interaktif dengan materi 
ditampilkan dalam bentuk teks dengan bantuan audio, contoh - contoh yang ditampilkan dalam bentuk gambar serta video yang dapat merangsang kreativitas dan respon siswa, serta terdapat searching materi yang membantu siswa untuk lebih melatih ingatan siswa terhadap materi yang ada. Media CD Interaktif perlu sekali dikembangkan untuk membantu meningkatkan pemahaman teoritis siswa terhadap mata pelajaran TIK khususnya pada semester II.

Pengembangan media CD Interaktif ini juga sangat didukung oleh hasil analisis karakteristik siswa. Hal ini diperoleh berdasarkan beberapa pendapat dari siswa yang sangat tertarik untuk lebih memahami materi TIK baik itu teori maupun prakteknya. Data analisis karakteristik siswa ini penulis peroleh melalui wawancara. Hasil wawancara menyatakan bahwa belajar TIK dapat menambah wawasan mereka terutama terhadap perkembangan teknologi, dapat mengaplikasikan komputer dengan baik tanpa takut akan salah menggunakan perangkat komputer serta penggunaan aplikasi yang terpasang pada komputer.

Materi - materi yang terdapat dalam media CD Interaktif ini sudah mengalami beberapa perbaikan. Perbaikan yang dilakukan berdasarkan hasil uji dari para ahli dan guru mata pelajaran TIK. Hal ini dilakukan untuk menyempurnakan isi materi dari media CD Interaktif sehingga siap diujikan di lapangan dan memberikan kemudahan kepada siswa dalam memahami isi materi media CD Interaktif TIK. Dengan media CD Interaktif tersebut siswa menjadi lebih cepat paham dan guru menjadi lebih mudah dalam menjelaskan materi kepada siswa.

Respon positif terhadap pengembangan media CD Interaktif, menunjukkan bahwa siswa tertarik dan termotivasi dalam belajar dengan menggunakan media CD Interaktif karena media pembelajaran ini penyampaian materinya jelas dan terorganisasi, serta tampilan dari media ini menarik perhatian siswa untuk mengetahui lebih dalam isi dari media CD Interaktif yang dapat menambah wawasan serta menambah kemandirian mereka dalam belajar.

\section{PENUTUP}

Berdasarkan hasil penelitian dan pembahasan yang telah diuraikan sebelumnya, dapat disimpulkan beberapa hal sebagai berikut.

(a) Pengembangan Media CD Interaktif Mata Pelajaran TIK Kelas VII SMP Negeri 6 Singaraja dirancang dan diimplementasikan dengan menggunakan dua model yaitu Dick and Carey untuk pengembangan isi media CD Interaktif dan Sequensial Linier untuk

JPTK, UNDIKSHA, Vol. 11 , No. 1, Januari 2014 : 13 - 24 
pengembangan media CD Interaktif, dan menggunakan software Macromedia Flash 8.0. Media pembelajaran ini dapat menjadi sumber belajar dan dapat dijadikan panduan belajar siswa.

(b) Respon siswa terhadap pengembangan Media CD Interaktif ini berada pada kategori positif sebesar $45 \%$.

Berdasarkan pengamatan penulis, terdapat beberapa hal yang dapat dijadikan bahan pertimbangan untuk ditindak lanjuti diantaranya:

(a) Diperlukan pengembangan lebih lanjut tehadap media CD Interaktif TIK ini agat tidak terbatas pada materi TIK kelas VII semester II.

(b) Bagi pembaca yang berminat dapat menjadikan CD Interaktif ini sebagai media pendukung dalam proses belajar mengajar.

(c) Bagi pembaca yang berminat dapat mengujikan CD Interaktif ini secara eksperimen.

(d) Perlu adanya penerapan media CD Interaktif ini di sekolah lain sehingga dapat dijadikan sumber belajar untuk meningkatkan kemandirian siswa.

(e) Dalam pengembangan media CD Interaktif sebaiknya dikaitkan dengan kondisi lingkungan dan karakter siswa sehingga mata pelajaran yang memerlukan ilustrasi dan praktek bisa lebih cepat dipahami.

\section{DAFTAR PUSTAKA}

Depdiknas. 2003. Media Pembelajaran. Jakarta: Depdiknas.

-----------. 2007. Naskah Akademik Kajian Kebijakan Kurikulum Mata Pelajaran TIK, Departemen Pendidikan Nasional

Eko Nugroho. Dr. Ir. 2008. Pengenalan Teori Warna. Yogyakarta: ANDI Yogyakarta.

Nurgiantoro. 2001. Metode Penelitian Pendidikan. Yogyakarta: ANDI Yogyakarta.

Nurkencana, Wayan dan Sunartana. 1990. Evaluasi Hasil Belajar. Surabaya: Usaha Nasional.

Mardalis. 2008. Metode Penelitian (Suatu Pendekatan Proposal). Jakarta: Bumi Aksana.

Misky, Dudi. 2005. Kamus Informasi \& Teknologi. Jakarta: EDSA Mahkota.

Roger S. Pressman, Ph.D. 2002. Rekayasa Perangkat Lunak. Yogyakarta: ANDI Yogyakarta. 
Santyasa, I Wayan. 2009. "Metode Penelitian Pengembangan dan Teori Pengembangan Modul". Makalah disajikan dalam Pelatihan bagi para guru TK, SMP, SMA, dan SMK tanggal 12-14 Januari 2009, di kecamatan Nusa Penida kabupaten Klungkung, Universitas Pendidikan Ganesha Singaraja.

Sudijono, Anas. 1995. Pengantar Evaluasi Pendidikan. Jakarta: PT. Raja Grafindo Persada.

Sugiyono. 2008. Metode Penelitian Pendidikan Pendekatan Kuantitatif, Kualitatif dan R \& D. Bandung: Alfabeta CV.

Sukardi, Prof. Ph.D. 2003. Metodologi Penelitian Pendidikan. Jakarta : PT. Bumi Aksara.

Suyanto, Muhammad. 2004. Analisis \& Desain Aplikasi Multimedia untuk Pemasaran. Yogyakarta: ANDI Yogyakarta.

Trianto. 2007. Model Pembelajaran Terpadu dalam Teori dan Praktek. Surabaya: Pustaka Ilmu.

JPTK, UNDIKSHA, Vol. 11 , No. 1, Januari 2014 : 13 - 24 